\title{
MARKA JAKO ZNACZNIK PROCESU KONSUMERYZACJI SPOLECZEŃSTWA
}

\author{
Anastazja SIER LECKA
}

\author{
Magister ekonomii, Kielce, POLSKA \\ DOI 10.25128/2304-1222.19.49.07
}

\begin{abstract}
The basic characteristics of consumption society such as: objectification, standardization and commercial ization were discussed in the article. Particular attention was given to the brand as an important element of consumerization of the society. The article reviews virtual, semiotic, quantitative, commercial, mediation and media functions of the brand which role was increased due to the excessive consumption in the modern world.
\end{abstract}

Keywords: consumption socjety, consumerization of the socjety, brand.

У роботі розглядаються основні характеристики консумпційного суспільства, такі як: реїфікація, стандартизація та комерціалізація. Особлива увага приділялася марки як важливому елементу консумеризації суспільства. Обговорювалося зростання ролі марки внаслідок надмірного споживання в сучасному світі, у тому числі іiї віртуальних, семіотичних, кількісних, комерційних, медіаційних і медійних функцій.

Ключові слова: консумпиійне суспільство, консумеризаџія суспільства, марка.

W pracy omówione zostały podstawowe cechy społeczeństwa konsumpcyjnego, takie jak: uprzedmiotowienie, standaryzacja oraz komercjalizacja. Szczególną uwagę poświęcono marce jako istotnemu elementowi konsumeryzacji społeczeństwa. Omówiono wzrost roli marki w rezultacie nadmiernej konsumpcji we współczesnym świecie z uwzględnieniem wirtualnej, semiotycznej, ilościowej, komercyjnej, mediacyjnej oraz medialnej funkcji marki.

Słowa kluczowe: społeczeństwo konsumpcyjne, konsumeryzacja społeczeństwa, marka.

O społeczeństwie konsumpcyjnym można mówić wtedy, gdy konsumpcja przestaje być domeną bogatych i klasy średniej i przekształca się w zjawisko masowe, a także wtedy, gdy wydatki konsumpcyjne ciągle wzrastają, stając się zasadniczym czynnikiem ekonomicznego funkcjonowania całego systemu, natomiast nienasycenie potrzeb staje się normą powszechną w odniesieniu do konsumpcji [Kulpa-Ogdowska 2006: 148]. XXI wiek prawdopodobnie można będzie nazwać erą konsumpcjonizmu. Coraz częściej 
ludzie nabywają dobra materialne $\mathrm{w}$ sposób nieprzemyślany, niezwiązany $\mathrm{z}$ rzeczywistym zapotrzebowaniem. Warto zauważyć, że zakupy nie są tylko nabywaniem produktów, lecz przekształcają się w postawę społeczną i tryb życia. Jednocześnie XXI wiek staje się erą społeczeństwa informacyjnego - społeczeństwa, w którym towarem podstawowym i ekonomiczną wartością nadrzędna staje się informacja. Informacja traktowana jest jako szczególne dobro niematerialne, równoważne lub nawet cenniejsze od dóbr materialnych. Społeczeństwo informacyjne charakteryzuje się zdolnością do skutecznego użytkowania systemów informatycznych i wykorzystuje usługi telekomunikacji do realizacji celów jego członków, w tym celów związanych z konsumpcją dóbr i usług [Ertmańska 2014: 348]. Jest to tylko jedno z wielu podejść w interpretacji społeczeństwa informacyjnego (bardziej szczegółowo na temat społeczeństwa informacyjnego i konsumeryzacji patrz: [Współczesny człowiek 2010; The Peculiarity of Man 2012]). Konsument zatracił obecnie dominację nad przedmiotem i w relacji ,podmiot - przedmiot" stał się elementem niemal biernym. To towary wybierają sobie klientów, rzeczy wyszukują sobie swych nabywców. Przedmioty dokonują w społeczeństwie informacyjno-konsumpcyjnym identyfikacji konsumenta. Nabywca już nie musi nic robić, nawet śledzić ceny, gdyż w ramach strategii uwodzenia i symulacji przedmioty zawsze oferują cenę deficytową - nadzwyczajną oraz jedyną okazję [Ramocka 2009: 101]. W nowoczesnym społeczeństwie konsumowanie stało się nieodłączną częścią życia, stając się wartością autoteliczną w hierarchii wartości człowieka. Konsumowanie nie jest już tylko kwestią zakupu produktów lecz stało się częścią stylu życia, sposobem spędzania czasu wolnego, wyznacznikiem społecznej przynależności, zarazem potrzebą i zewnętrznym przymusem posiadania dóbr, co do których nabraliśmy przekonania, że są nam niezbędne [Piłat-Borcuch 2011: 231] i niekoniecznie z własnej woli.

Teoretyk społeczeństwa konsumpcyjnego J. Baudrillard fenomen konsumpcji określa jako zjawisko przenikające wszystkie obszary funkcjonowania współczesnego społeczeństwa oraz oddziałujące niemal na każdy fragment doświadczenia ludzkiego. Wg niego, konsumpcja ,jest czynnymi zbi orowymzachowaniem, jest przymusemi nakazem, moralnością i instytucją. Jest całym systemem wartości, wraz ze wszystkim tym, co pojęcie to implikuje, czyli pełnionymi przezeń funkcjami integracji grupowej i kontroli społecznej” [Baudrillard 2006: 94]. Jak słusznie zauważa M. Piłat-Borcuch „Wszechobecność konsumpcji jest faktem. Konsumpcja stała się czynnikiemzarówno inkluzji, jak i ekskluzji społecznej, implikując - szczególnie za sprawą kontroli społecznej, społeczne podziały. Aspiracje związane z potrzebą przynależności do konkretnej grupy społecznej, pociągają za sobą konsumpcyjne wybory danej jednostki, sytuujące ją w danej grupie bądź poza nią" [Piłat-Borcuch 2011: 232].

We współczesnym świecie dominacja konsumpcji zaczyna pełnić rolę jednego z kluczowych regulatorów procesów społecznych, przytłaczając inne sfery życia, w tym rozwój intelektual ny czy działalność społecznie pożyteczną. Przewaga wartości materialnych i ilościowych sprawia, iż głównymi miernikami rozwoju stają się ciągły wzrost gospodarczy oraz wydajność [zob.: Augustyniak 2013: 4]. Według F. Byloka konsumpcja postrzegana jest jako jeden z ważniejszych sposobów samoekspresji oraz wyróżnik stylu 
życia. Stała się ona kołem zamachowym współczesnego społeczeństwa [zob. Radziukiewicz 2013: 151-152]. Określenie ,społeczeństwo konsumpcyjne” odnosi się głównie do współczesnych społeczeństw zachodnich, które w coraz większym stopniu są organizowane zgodnie $\mathrm{z}$ wymogami konsumpcji, a nie produkcji materiałów czy usług. Twierdzi się, że pojawiło się ono wraz z rozwojem późnego kapitalizmu, który związany jest bezpośrednio $\mathrm{z}$ powszechnością produkcji masowej [Terada 2004: 10]. Chodzi przede wszystkim o społeczeństwo amerykańskie, po części też zachodnioeuropejskie, ale paradoksalnie również punktowo dotyczy megapolisów w innych krajach.

M. Radziukiewicz zwraca uwagę na semiotyczny charakter procesów konsumpcjonistycznych. W procesie konsumpcji nie chodzi zatem o potrzebę posiadania dóbr konsumpcyjnych, lecz o potrzebę komunikowania się z wykorzystaniem dóbr konsumpcyjnych jako znaków. Jej celem jest uzyskanie społecznej aprobaty (społecznego znaczenia). Konsumpcjonizm utożsamiany jest zarówno z ideologią - wizją życia związaną z kulturą konsumpcji i jej wartościami, jak i stylem życia - nieadekwatną do potrzeb konsumpcją [zob: Radziukiewicz 2013: 153].

Wyróżnić można następujące składowe społeczeństwa konsumpcyjnego. Pierwszą istotną cechą tego sposobu życia jest uprzedmiotowienie, jako podstawa konsumpcjonizmu w wąskim znaczeniu. Zakłada ono następujące procesy występujące w ogólnym obrazie świata: urealnienie pojęć wirtualnych, przekształcające je w coś rzeczywistego; fizjologizacja potrzeb, a więc zastąpienie wartości kulturowo-cywilizacyjnych poprzez potrzeby typowo zwierzęce; wartość rzeczy zaczyna przejmować dominację nad wartościami relacji interpersonalnych, przejawia się to zwiększeniem znaczenia zaspoka jania potrzeb zmysłowych, kosztem potrzeb relaksacyjnych; przeniesienie punktu ciężkości w kierunku pracy oraz konsumpcji, co za tym idzie upodmiotowienie rzeczy prowadzi do uprzedmiotowienia człowieka, który zaczyna być postrzegany jako narzędzie pracy lub przedmiot konsumpcji - depersonalizacja [Leszczak 2012: 16-17].

Drugą cechą społeczeństwa konsumpcyjnego jest standaryzacja jako podstawa „uilościowienia” konsumpcji. Chodzi o dominację czynnika ilościowego nad jakościowym, w obrazie świata człowieka współczesnego (uprzedmiotowanego). Wartości współczesnych ludzi stają się ujednolicone, umasowione, specyficzne cechy poprzez multiplikację stają się wzorcami do naśladowania, co w konsekwencji skutkuje standaryzacją życia społecznego. Drugą stroną ,uilościowienia” życia w społeczeństwie konsumpcyjnym jest świadome naśladownictwo, a więc konformizm z wyboru. Ta bezmyślność bierze się z obniżenia świadomości sedna swoich zachowań, gdyż dla współczesnego człowieka dominującą wartością staje się ilość kosztem jakości. Kolejną istotną cechą społeczeństwa konsumpcyjnego jest komercjalizacja jako podstawa formalizacji oraz semiotyzacji konsumpcji. Odbywa się to między innymi poprzez utylitaryzację wartości, a więc ma miejsce kult maksymalizacji korzyści oraz innowacyjności. Również następuje tu merkantylizacja zachowania, polegająca na wprowadzeniu zmian jakościowych w hierarchii wartości, a więc zdominowanie wszystkich wartości przez czynnik korzyści materialnej [tamże: 20-22]. 
Istnieje wiele cech społeczeństwa postindustrialnego, które opisują jednocześnie stan społeczeństwa konsumpcyjnego. Między innymi warto zwrócić uwagę na rozpowszechniający się dobrobyt materialny, zmniejszające się znaczenie sektora przemysłowego i rozwój sektora usług, postępująca specjalizacja zawodowa, „umasowienie” kultury, skrócenie czasu pracy na rzecz czasu wolnego a także zwiększenie znaczenia czasu wolnego jako wyznacznika jakości życia [Adamczyk 2012: 62-63].

Następnym etapem konsumeryzacji jest komercjalizacja podaży i popytu, zakłada jąca przekształcenie wszystkiego w towar, który można sprzedać (zasada „wszystko jest na sprzedaż”), jednak charakter totalny komercjalizacja życia społecznego zaczyna nabywać dopiero w następnym etapie gdy wszystko staje się towarem do nabycia (zasada „wszystko do kupienia”). Podsumowującym etapem staje się komercjalizacja wartości polegająca na podporządkowaniu wszystkich wartości czynnikowi komercyjnemu [Leszczak 2012: 20-22].

Aby zrozumieć istotę społeczeństwa informacyjnego oraz procesów, które je kreują niezbędne jest wyjaśnienie takich pojęć jak wirtualizacja, semiotyzacja oraz mediatyzacja. Wirtualizacja doświadczenia realnego dotyczy znaczącej zmiany proporcji między rzeczywistością empiryczną a inteligibilną (racjonalną). To zjawisko przejawia Się w zaniku czynnika energomaterialnego w dziedzinach, które tradycyjnie traktowano jako sfera życia realnego (gospodarka, życie społeczno-polityczne, życie codzienne). Semiotyzacja działalności przedmiotowo-manipulacyjnej zakłada przeniesienie punktu ciężkości z czynności fizyczno-manipulacyjnych (działania na przedmiotach fizycznych oraz wiedza o nich) na czynności semiotyczne (operowanie przedmiotami sygnałowymi i komuni katami) [Leszczak 2010: 18-21]. Mediatyzacja zaś w społeczeństwie konsumpcyjnympolega na przeniesieniu punktu ciężkości z komunikacji bezpośredniej na pośrednią - zdystansowaną i często bezosobową. Najważniejszym wyróżnikiem komunikacji mediacyjnej jest możliwość nawiązania bądź zerwania tej komunikacji w każdej chwili, co niemożliwe jest w bezpośredniej (osobowej) formie komunikacji. Stwarza to iluzję realnej komunikacji, gdyż słyszymy i widzimy rozmówcę, lecz pojawia się tu złudzenie wolności w zarządzaniu naszą przestrzenią komunikatywną [tamże: 22-23].

Coraz częściej konsumenci sięgają po produkty, które wiążą się z pewnym przekazem społecznym i pozwalają w jakiś sposób pomóc tam, gdzie zachodzi taka potrzeba. Jest to związane z jedną z obecnych sił nabywczych, jaką jest tzw. ,pokolenie Y”. Przedstawiciele tej generacji przywiązują większą wagę do ich oddziaływania na środowisko Ziemi, mniejszą natomiast do gromadzenia pieniędzy oraz dóbr. Jest to pokolenie, które zrozumiało że konsumpcja rzadko przynosi poczucie szczęścia [zob.: Leńczuk]. Nabywcy pokolenia Y chcą dostać od marki coś, co zaspokoiłoby ich potrzebę postrzegania siebie jako świadomych konsumentów. Konsumpcja stała się symbolem, manifestem - konsument kupuje ponieważ wspiera swoimi decyzjami zakupowymi pewne wartości, które wyznawane są także przez daną markę. Nabywcy utożsamiają się z propagowanymi przez markę stylem życia oraz jej filozofią. Obecnie robiąc zakupy, konsumenci oczekują także spełnienia duchowego. Konsumpcja pochłania coraz więcej czasu oraz energii, stała się na tyle istotnym aspektem życia, że pojawiło się oczekiwanie, 
że oprócz zaspokajania potrzeb użytkowych oraz emocjonalnych dostarczyć ma również poczucia sensu. Współcześni konsumenci oczekują, że marki będą podejmować działania mające na celu polepszenie warunków życia, dbanie o środowisko czy też pomoc W rozwiązaniu istotnych problemów społecznych. Spełnienie duchowe ma szansę stać się wyróżnikiem marki [zob. więcej: Dyrcz 2014]

Zdaniem G. Adamczyka, do istotnych czynników rozwoju konsumpcji masowej należy wykształcenie się konceptu sklepu samoobsługowego i związane $\mathrm{z}$ tym zmniejszenie roli sprzedawcy $\mathrm{w}$ procesie zakupu, wyposażenie opakowania $\mathrm{w}$ funkcje komunikacyjne, rozwój reklamy masowej oraz, co jest najistotniejsze - wzrost roli i znaczenia marki handl owej [Adamczyk 2012: 62-63]. Marka odgrywa na współczesnym rynku coraz większe znaczenie. Fenomen marki jest skondensowanym znacznikiem konsumpcjonizmu jako takiego. Jest to funkcja wirtualna (jest informacją), semiotyczna (jest znakiem), ilościową (ma wymiar pieniężny), komercyjną (jest towarem), mediacyjną (jest pośrednim ogniwem między towarem a konsumentem) i medialną (jest czynną funkcją reklamową). Konsumenci w swoich decyzjach zakupowych coraz częściej kierują się właśnie tym kryterium. W rezultacie nadmiernej konsumpcji we współczesnym świecie rola marki uwidacznia się coraz bardziej. Badania pokazują, że aż trzy czwarte respondentów z ogólnej próby w najróżniejszych badaniach marketingowych chciałoby, by rolę gwarantów produktów sprzedawanych online odgrywały marki. Sześciu na dziesięciu badanych widzi w markach pośredników między sobą a sprzedającymi lub kupującymi. Aż 94\% respondentów w Polsce chciałoby, by marki stanowiły gwarancję jakości oraz autentyczności produktów sprzedawanych przez Internet, natomiast 87\% uważa, iż gwarancje marki powinny objąć każdego, kto kupuje produkt - tylko pierwszego nabywcę. Przeważająca większość respondentów oczekuje, że marki pomogą przejść na konsumpcję bezpieczniejszą dla Ziemi oraz zdrowia społeczności. Aż 91\% badanych podziwia przedsiębiorstwa, które starają się znaleźć sposób na ograniczenie marnotrawstwa. Zwiększa się liczba marek, które ułatwiają swoim klientom odsprzedaż czy też oddanie towarów, których klienci już nie potrzebują. W Polsce 95\% ankietowanych podziwia marki, które zachęcają swoich klientów do recyklingu, a 75\% sądzi, że firma powinna pomagać klientom w odsprzedaży swoich produktów [Inteligentna konsumpcja 2014].

Ze względu na coraz większą konkurencję jednym z kluczowych zagadnień efektywności marketingu staje się nazewnictwo zarówno firm, jak i produktów. Razem z ilością nowych producentów i produktów rośnie liczba nazw. Przy tym czasami prezentacja marki oraz nazwa produktu jest przeprowadzana w taki sposób, aby stworzyć wrażenie, iż jest to marka firmy. Nowa nazwa produktu jest kluczową decyzją dla sposobu komunikowania marki. Nazewnictwo produktów (ang. naming) musi być przygotowane na różne zastosowania w działaniach marketingowychoraz promocyjnych. Zła nazwa produktu szkodzi oraz ogranicza markę [zob: Kiedynazwa produktujestsilna]. Nadanie nazwy produktowi jest decyzją strategiczną, gdyż de facto w społeczeństwie informacyjno-konsumpcyjnym sprzedaje się nie towar, a marka i nazwa. Odpowiednia nazwa umożliwia zbudowanie silnej oraz rozpoznawalnej marki. Za pomocą nazwy 
budowanajest marka, a w rezultacie dany produkt uzyskuje wyższą cenę niż jego funkcjonalny odpowiednik. Dzieje się tak ponieważ konsument nie jest przekonany co do właściwości danego produktu, zaś reputacja przedsiębiorstwa pozwala rozwiać wątpliwości klienta. Odpowiednie dobranie nazwy to początek strategii marketingowej marki. Kreatywne nazwy to podstawa unikal nego pozycjonowania konkurencyjnego. Forma jaką przyjmują nazwy produktów, zależy od wielu czynników. Niektórzy uważają, że nazwa firmy to tylko sposób oznakowania lub odróżnienia firmy. Gdy nazwa jest unikalna, wspiera również budowanie pozycji rynkowej marki. Kreatywne nazwy powstają niekiedy przez przypadek. Najczęściej jednak choć nazwą może być tylko zestawienie kilku liter, na ich stworzenie poświęca się wiele pracy, badań oraz testów [zob.: Jak powstaja...]. Zastrzeżone nazwy produktów oraz firm często są warte miliony.

W najnowszej odsłonie raportu Best Global Brands 2018 agencji Interbrand najdroższym brandem została marka Apple. Wartość tej marki szacuje się na 214.480 milionów dolarów. Drugie miejsce zajęła marka Google, która w zeszłym roku była liderem w tym rankingu. Jej wartość szacuje się na 155.506 milionów dolarów. Trzecie miejsce należy do Amazon - 100.764 milionów dolarów, natomiast czwarte marka Microsoft 92.715 milionów dolarów. Najszybciej zyskującą na wartości marką jest Amazon wzrost o 56 \% oraz Nefflix - wzrost wartości marki o 45\% [Best Global Brands 2018].

Oprócz Interbrand jest jeszcze jeden podmiot, który co roku przygotowuje zestawienie 100 najdroższych marek świata - Millward Brown. Oba ośrodki wychodzą z podobnego założenia, że rozpoznawalne logo jest jedną z najważniejszych składowych kapitału spółek, która generuje realne przychody. Wartość marki nie jest jednak pojęciem precyzyjnie zdefiniowanym, dlatego też obydwie firmy stosują nieco inne kryteria jej oceny. W rezultacie co roku obie listy najwartościowszych brandów świata, choć podobne, różnią się pomiędzy sobą w wielu aspektach. Zestawień tych nie powinno się traktować zbyt dosłownie, lecz raczej jako wskaźniki pewnych rynkowych trendów.

Światowe projekty nazewnicze to ogromne przedsięwzięcia, które są bardzo drogie i czasochłonne. Pracują przy nich całe zarządy oraz działy marketingu specjalistycznych firm. Aby stworzyć dobrą nazwę potrzebny jest czas, zaangażowanie, współpraca, a czasem genialny pomysł. Warto zauważyć, że czasem wystarczy nie stworzyć złej nazwy. Omijając powszechne błędy powstaje szansa na stworzenie nazwy, która nie tylko wzbudzi zachwyt wspólników lecz będzie służyć przedsiębiorstwu przez lata. Pierwszym błędem w pracy nad nazwą jest kierowanie się autorytetem. Każdy właściciel chce mieć największy wpływ na to jak będzie się nazywać firma. Nie jest to jednak dobre rozwiązanie, gdyż dobre pomysły to takie, które zasługują na argumenty oraz dyskusję. Nie jest także dobrym rozwiązaniem angażowanie do projektu nazwy wszystkich dookoła. Po pierwsze zajmie to zdecydowanie zbyt dużo czasu, odrzucone zostaną projekty dużej grupy osób, co spotka się z negatywnym podejściem grupy, a uzyskany kompromis będzie nazwą bez właściwości, która zadowala wszystkich. Zmorą nazewnictwa są również krótkotrwałe mody. Moda nie ma nic wspólnego z kreowaniem silnej marki. To co jest modne w momencie tworzenia nazwy może już być szybko zapomniane, dlatego myśląc o dobrego wizerunku na dłuższą metę nie warto kierować się modą. Nazwa 
produktu powinna przenosić dobre skojarzenia. Jest to ważny i cenny element, lecz tylko do momentu, gdy nie jest nadużywany [zob.: Naming].

W związku ze stopniowym przechodzeniem w fazę powszechnie zwaną społeczeństwem informacyjno-konsumpcyjnym istotnie wzrosła rola komercyjnego nazewnictwa, które jako zjawisko informacyjne przekształciło się w pełnowartościowy towar. Nie tylko uczestniczy on w kreowaniu wartości podstawowego produktu lecz również zaczął odgrywać rolę zupełnie samodzielnych produktów konkurujących ze sobą na rynku i posiadających własną rynkową wartość - cenę brandu. Ma to wpływ również na konsumenta, który w coraz większym stopniu pragnie nabywać nie tylko produkt podstawowy lecz również modny oraz powszechnie znany brand.

\section{LITERATURA}

Adamczyk, G. Moralność w warunkach społeczeństwa konsumpcyjnego, „Zeszyty Naur koweKUL", 2012, $55 \mathrm{nr} 1$ (217).

Augustyniak, M., Społeczeństwo konsumpcyjne w refleksji filozoficznej i językowej, w Ochrona konsumenta w prawie polskim i unii europejskiej, pod red. M. Królikowskiej-Olczak, B. Pachucy-Smulskiej, C.H.Beck 2013, s. 1-11.

Baudrillard, J. Społeczeństwo konsumpcyjne. Jego mity i struktura, Warszawa 2006.

Best Global Brands 2018 w: Interbrand, URL: https://www.interbrand.com/bestbrands/best-gl obal-brands/2018/ [25.04.2019].

Dyrcz, K. Technologie, dane $i$ duchowość, czyli trendy marketingowe na 2014 rok, 13.02.2014, w: Marteker+, URL: https://marketerplus.pl/teksty/artykuly/technologie-dane-duchowosc-trendy-marketingowe-2014-rok/ [23.04.2019].

Ertmańska, K. Konsument odpowiedzialny w społeczeństwie informacyjnym, „Marketing i Rynek", 2014, nr 11, s. 348 - 355.

Inteligentna konsumpcja i rola marek w obliczu „ekonomii w sam raz” w: WPROST, 26.08.2014, URL: http://informacjehavasworldwide.pl/pr/286856/inteligentna konsumpcjai-rola-marek-w-obliczu-ekonomii-w-sam-raz [13.04.2015].

Jak powstaja kreatywne nazwy dla firm i marek? w: CODES Brand \& Corporatel dentity, URL: $\quad$ http://www.identity.pl/jak-powstaja-kreatywne-nazwy-dla-firm-i-marek/ [12.04.2015].

Kiedy nazwa produktu jest silna i perswazyjna? w: CODES Brand \& Corporate Identity, URL: $\quad h$ ttp://www.identity.pl/kiedy-nazwa-produktu-jest-silna-i-perswazyjna/ [12.04.2015].

Kulpa-Ogdowska, A. Wtaczeni $i$ wyłaczeni z globalnej sieci. Społeczne konsekwencje rozwoju nowoczesnych technologii i konsumeryzmu, w Nierówności społeczne a wzrost gospodarczy. Problemy globalizacji i regionalizacji, pod red. $M$. G. Woźniak, Uniwersytet Rzeszowski, Rzeszów 2006, s. 138-154.

Leńczuk, J. Litery dzielące generacje - o różnicach między pokoleniem X, Y i Z, w: Stapler, URL: http://stapler.pl/hydepark/litery-dzielace-generacje-o-roznicachmiedzy-pokoleniem-X-y [23.04.2019]. 
Leszczak, O.. Paradoksy konsumpcjonizmu. Typologia i lingwosemiotyka, "The Peculiarity of Man", 2012, nr 15, s. 9-26.

Leszczak, O. Podstawowe cechy spoleczeństwa informacyjnego w aspekcie funkcjonalnopragmatycznej teorii doświadczenia, w: Współczesny człowiek w społeczeństwie informacyjnym: egzystencja - ideologia - moralność, pod red. R. Stefańskiego i A. Zamojskiego, Adam Marszałek, Toruń 2010.

Naming - jak nie stworzyć złej nazwy? w: nf.pl, URL: http://nf.pl/po-pracy/naming-jakniestworzyc-zlej-nazwy,,13469,295 [12.04.2015].

Piłat-Borcuch, M. Konsument jako „produkt” spoteczeństwa konsumpcyjnego?, „Studia i Materiały. Miscellanea Oeconomicae", 2011, rok 15, nr 1, s. 231-240.

Radziukiewic,, M. Recenzja ksiażki F. Byloka pt. „Konsumpcja, konsument $i$ spoleczeństwo konsumpcyjne” Wydawnictwo Naukowe „Śląsk”, Katowice 2013, „Konsumpcjai rozwój" 5, nr 2, s. 151-153.

Terada, Y. Rozwój spoleczeństwa konsumpcyjnego i różne koncepcje wolności, W: W cywilizacji konsumpcyjnej, pod red. M.Golki, Poznań 2004, s. 9-26.

“The Peculiarity of Man", nr 15, Torun 2012.

Współczesny człowiek w społeczeństwie informacyjnym: egzystencja - ideologia- moralność, pod red. R. Stefańskiego i A. Zamojskiego, Adam Marszałek, Toruń 2010. 